Neurosurg Focus 20 (4):E24, 2006

\title{
Hypoxia in the tumorigenesis of gliomas and as a potential target for therapeutic measures
}

\author{
Randy L. Jensen, M.D., Ph.D. \\ Department of Neurosurgery, University of Utah; and Huntsman Cancer Institute, \\ Salt Lake City, Utah
}

\begin{abstract}
$\checkmark$ In this article, the author provides a brief description of the role of hypoxia in the tumorigenesis of gliomas and suggests potential ways of exploiting this role to design treatment modalities. Tumor hypoxia predicts the likelihood of metastases, tumor recurrence, resistance to chemotherapy and radiation therapy, invasive potential, and decreased patient survival for many human malignancies. Various methods of measurement of tumor hypoxia are discussed, including direct measurement and imaging methods.

The role of hypoxia-responsive molecules, especially hypoxia-inducible factor-1 (HIF-1), in glioma tumorigenesis is explored. Treatment modalities regulated by hypoxia are proposed and some potential strategies reviewed. The progression of a low-grade astrocytoma to a glioblastoma multiforme may be mediated by hypoxia-induced phenotypic changes and subsequent clonal selection of cells that overexpress hypoxia-responsive molecules, such as HIF-1. In this model, intratumoral hypoxia causes genetic changes that produce a microenvironment that selects for cells of a more aggressive phenotype.
\end{abstract}

KEY WORDS • hypoxia • tumorigenesis • glioblastoma multiforme • vascularization

$\mathrm{G}$ LIOBLASTOMA multiforme is the most common and most malignant brain tumor in humans, with a survival rate of only 0 to $5 \%$ at 5 years after presentation despite therapy. Although LGAs usually have a much better prognosis, most eventually progress to become higher-grade tumors. It is not understood what triggers this transformation, but features such as intratumoral necrosis and vascular endothelial proliferation distinguish high-grade from low-grade tumors. ${ }^{75,105}$

In this paper, I propose the hypothesis that as an LGA outgrows its blood supply, small areas of hypoxia develop. The cells best able to respond to this hypoxic stress are clonally selected, and the tumor progresses to become a GBM. These cells have the ability to promote angiogenesis, a higher proliferation potential, and a decreased response to therapeutic measures. I hypothesize that this effect is mediated by HRMs such as HIF-1 $\alpha$. A better understanding of this process and, eventually, the development of treatments that target HIF- $1 \alpha$ or similar HRMs in human gliomas could result in a better prognosis for patients with this devastating disease.

Abbreviations used in this paper: GBM = glioblastoma multiforme; HIF-1 = hypoxia-inducible factor-1; HRE = hypoxia response element; HRM = hypoxia-responsive molecule; LGA = low-grade astrocytoma; shRNA = short hairpin RNA; siRNA = small interfering RNA; VEGF = vascular endothelial growth factor; VHL = von Hippel-Lindau.

\section{Hypoxia and Tumorigenesis}

Glioblastoma multiforme is one of the most highly vascularized human tumors, but this microcirculation is functionally very inefficient compared with that of normal brain tissue. ${ }^{14,50,60,64,150}$ Intratumoral necrosis, the hallmark of GBM, is found in both small and large tumors, suggesting that necrosis may not simply be due to inadequate vascular supply but instead may be a result of intrinsic molecular or genetic changes within the tumor. ${ }^{117}$ Direct and indirect measurements of tumor hypoxia in human GBMs have not cleared up this controversy. .11,100,113,151 $^{2}$

Evidence suggests that hypoxia plays a role in the malignant transformation of cells and subsequent tumor growth (Fig. 1). In a number of different human cancers, tissue hypoxia predicts the likelihood of metastases, ${ }^{144}$ tumor recurrence, ${ }^{59}$ resistance to chemotherapy and radiation therapy, ${ }^{41,118,130,159}$ invasion, ${ }^{31,48}$ and decreased patient survival. ${ }^{58,156}$ In fact, the degree of necrosis within a GBM correlates inversely with patient outcome and survival. ${ }^{52}$, ${ }_{76,80}$ Hypoxic stress has been linked to several phenotypic changes that are fundamental to malignant progression. ${ }^{129}$, ${ }^{131}$ This can be mediated through genomic instability, loss of apoptotic potential, alterations of gene expression, and induction of angiogenesis. ${ }^{47,67,117,126,141,145}$ All of these processes are exhibited in GBMs. ${ }^{42,53,72,88}$ I hypothesize that hypoxic stress causes a clonal expansion of cells with increased angiogenic potential and decreased apoptotic potential and that the result is a more aggressive tumor phenotype, in this case GBM (Fig. 2). ${ }^{43,110}$ 


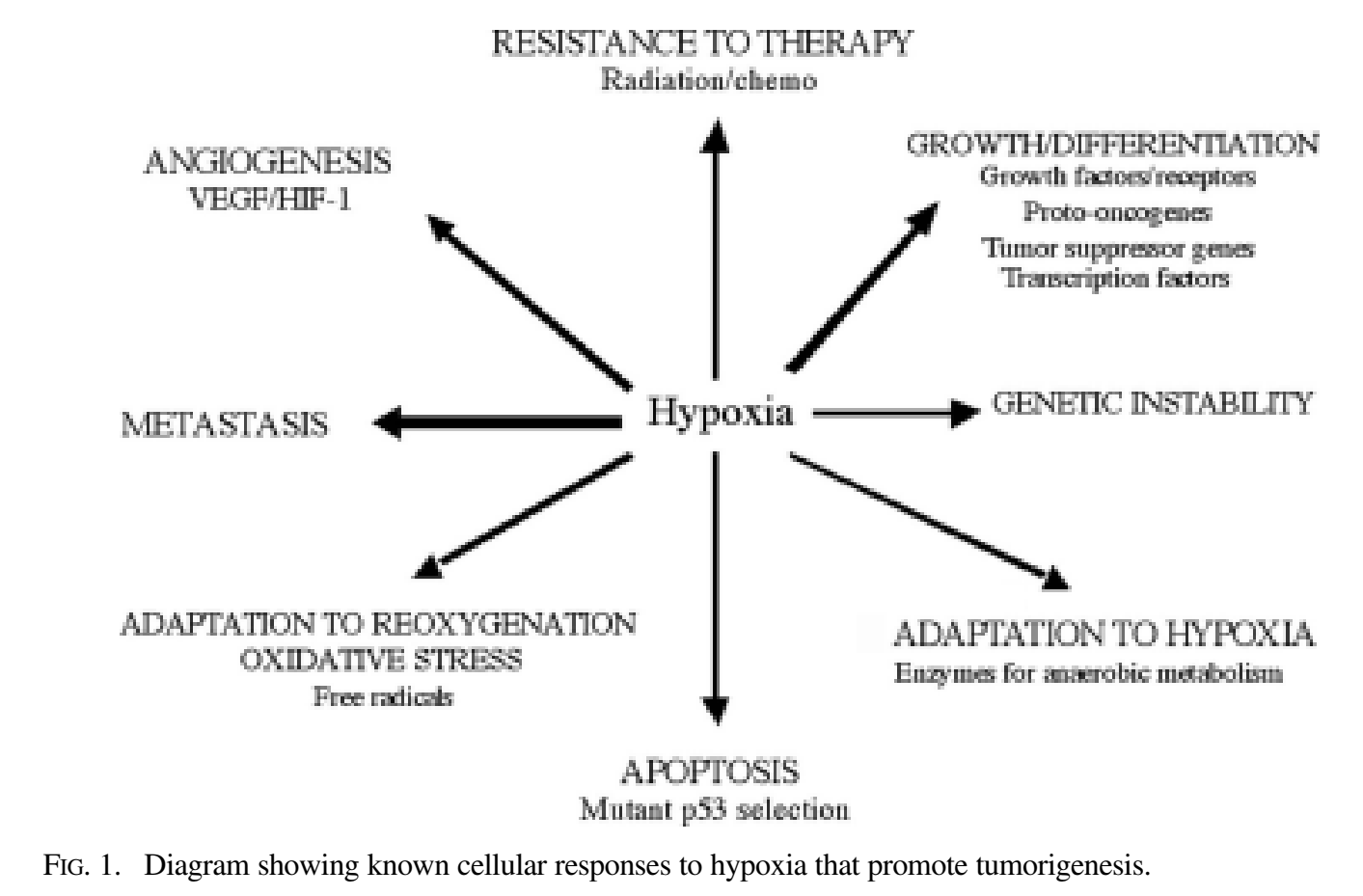

\section{Direct Measurement of Tumor Hypoxia}

Intracellular hypoxia can be measured by biochemical markers of tissue hypoxia. The nitroimidazole derivatives EF5 $^{87}$ and pimonidazole ${ }^{7,121}$ have been used to label hypoxic cells in animal and human tumors. At low $\mathrm{O}_{2}$ concentrations, these markers undergo bioreduction by nitroreductases and bind to cellular macromolecules, which can be measured using immunohistochemical methods. ${ }^{121,155}$ As a demonstration of this technique, we grew U251 GBM cells subcutaneously in athymic mice and after 60 days injected the mice with pimonidazole hydrochloride (Hypoxyprobe-1; Natural Pharmacia International, Inc., Belmont, MA). This drug is bioreductive-it becomes charged and trapped within the cell under hypoxic conditions. ${ }^{111,158}$ The tumors were removed and fixed in formalin. The tissue was placed on glass slides, and cells with pimonidazole (hypoxic cells) were visualized using immunohistochemical methods with an antipimonidazole monoclonal antibody. ${ }^{7,12}$ On similar sections, the tumor vasculature was visualized using antibodies directed against a vascular marker (CD31 monoclonal antibody; Santa Cruz Biotechnology, Santa Cruz, CA). The U251 cells showed significant areas of necrosis with surrounding areas of hypoxia that correlate with pimonidazole staining (Fig. 3).

Polarographic $\mathrm{O}_{2}$ microelectrodes have also been used to determine intratumoral hypoxia in various tumors but have produced mixed results in the limited number of brain tumors studied. $9,29,55,69,71,113,155$ These studies of polarographic $\mathrm{O}_{2}$ microelectrodes lack spatial correlation with preoperative imaging or intracellular hypoxia measurement. The lack of direct correlation between measurements of polarographic $\mathrm{O}_{2}$ microelectrodes, biochemical data, and imaging studies might account for the discrepancy of the prior work. With current stereotactic techniques and the ability to register anatomical location by using the preoperative imaging studies described later, this may be overcome in the future.

\section{Imaging Measurement of Tumor Vascularity, Hypoxia, and Perfusion}

Peritumoral edema is a condition of increased vascular permeability associated with GBM that can be measured using MR imaging. This imaging technology has also been used to map changes in blood volume fraction and vascular functionality associated with angiogenesis..$^{1,2,19,25}$,

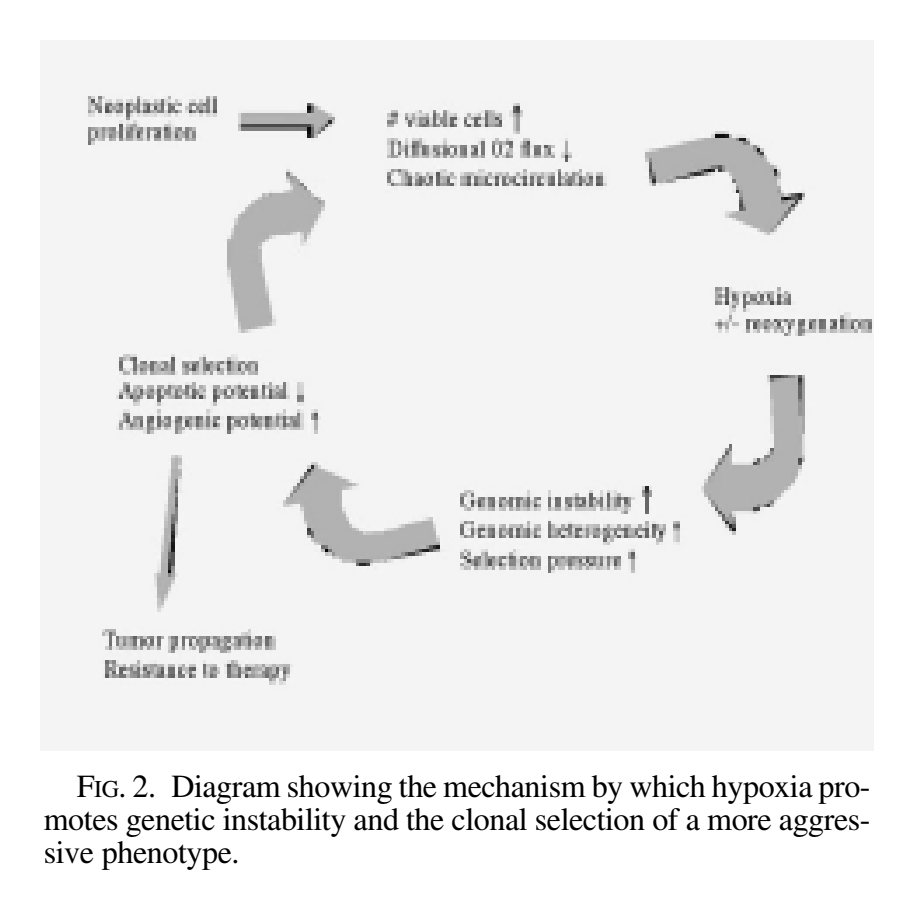

Neurosurg. Focus / Volume 20 / April, 2006 

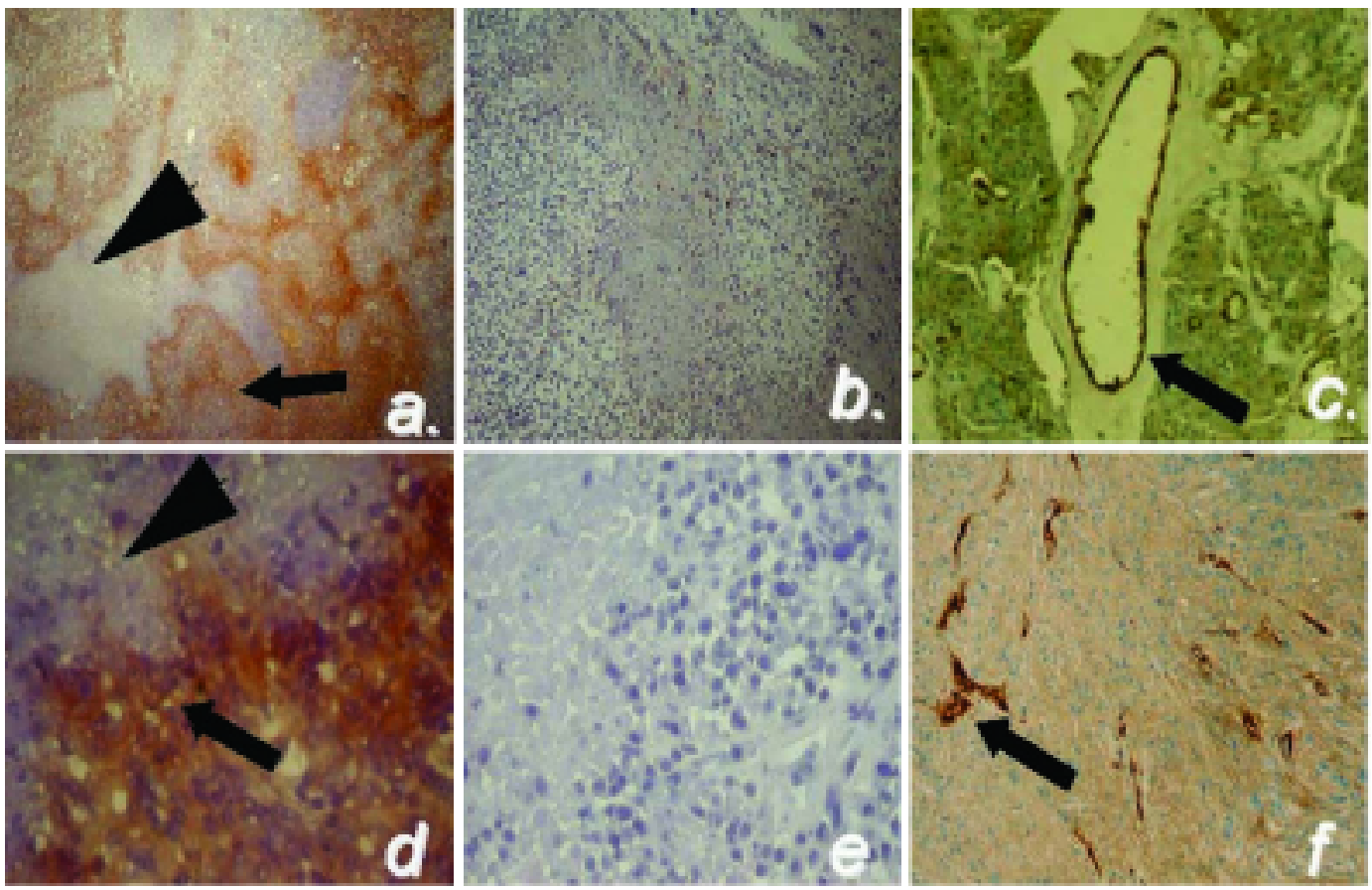

FIG. 3. Photomicrographs showing the immunohistochemical findings in U251 glioma cells grown subcutaneously in athymic mice. a and d: Tissue sections with pimonidazole staining (brown areas, arrows) in presumed hypoxic regions surrounding areas of necrosis (arrowheads). $\quad \mathrm{b}$ and e: Tissue sections obtained in negative controls (animals not injected with pimonidazole before tumor removal). $\quad \mathrm{c}$ and $\mathrm{f}$ : Tissue sections stained with CD31 antibody demonstrating intratumoral vasculature. High-power view demonstrating vessel diameter and intraluminal area (c). Lower-power view demonstrating vessel number and vascular area in relationship to total tumor area (f). Original magnifications $\times 10$ (a, c, and $\mathrm{f}) ; \times 40(\mathrm{~b}, \mathrm{~d}$, and e).

32,46,49,77,143 Dynamic contrast-enhanced MR imaging can provide measurements of tumor perfusion and vascularity by using kinetic modeling of tumor contrast uptake over time. ${ }^{10,38,94,101,142,149}$ It has the potential to predict intratumoral blood flow and vascular permeability preoperatively. After data collection, the relative cerebral blood-volume maps are derived on a voxel-by-voxel basis from the dynamic imaging sets. One disadvantage is that the significant amount of postprocessing necessary for data acquisition is time consuming and requires technical expertise. . $^{10,32,104,143}$

Magnetic resonance spectroscopy is an emerging technology that allows for in vivo chemical analysis of tissue during MR imaging. ${ }^{96}$ With this technology, the distributions of various metabolite concentrations including $\mathrm{N}$ acetyl aspartate, N-phosphocholine (choline), and lactate can be determined. Increased lactate, choline, or creatinine and decreased $N$-acetyl aspartate reflect the neuronal tissue loss and increased membrane synthesis that is known to occur in GBM. ${ }^{6,44,162}$ At present, whether increased lactate peaks are due predominantly to hypoxia or to increased tumor metabolism is not known. ${ }^{34}$

Positron emission tomography provides the ability to measure the concentrations of positron-emitting radioisotopes within the tissues of living patients. Positron emission tomography of 2-nitroimidazole compounds, such as $\left[{ }^{18} \mathrm{~F}\right]$ fluoromisonidazole, has been used to identify hypoxic tumors (including gliomas) in humans. ${ }^{9,114-116}$ The most studied of these compounds is $\left[{ }^{18} \mathrm{~F}\right]$ fluoromisonidazole,
${ }^{122,148}$ although its slow clearance from normoxic tissues and the difficulty in obtaining it has led to a search for newer radiotracers. Another compound, copper diacetylbis[N4-methylthiosemicarbazone] was recently discovered to have higher uptake in hypoxic tissues than the nitroimidazoles do, and it can yield high-quality images as soon as 20 minutes after injection. ${ }^{84,85,97}$ It is also flexible in that it can be labeled with any of several positron-emitting copper radioisotopes. In addition to these advantages, it already has been used in a few human clinical trials. ${ }^{13,33,39}$

Molecules associated with tumor vascularity, such as VEGF, have been correlated with peritumoral edema and an increase in brain tumor malignancy. ${ }^{45}$ No direct imaging techniques are available to measure the presence of VEGF or similar molecules. At present, it appears that correlating imaging characteristics with tumor histology and biology, although indirect, is the best method available for examining these relationships. Among molecules that are thought to regulate angiogenesis are those under the control of hypoxic regulation.

\section{Hypoxia-Inducible Molecules}

The transcription factor HIF-1 is the best-characterized HRM. It is composed of two subunits, HIF-1 $\beta$ and HIF$1 \alpha$, both of which are constitutively expressed and not significantly altered by hypoxia. Although HIF-1 $\beta$ protein is found in normoxic cells, almost no HIF- $1 \alpha$ protein can be 


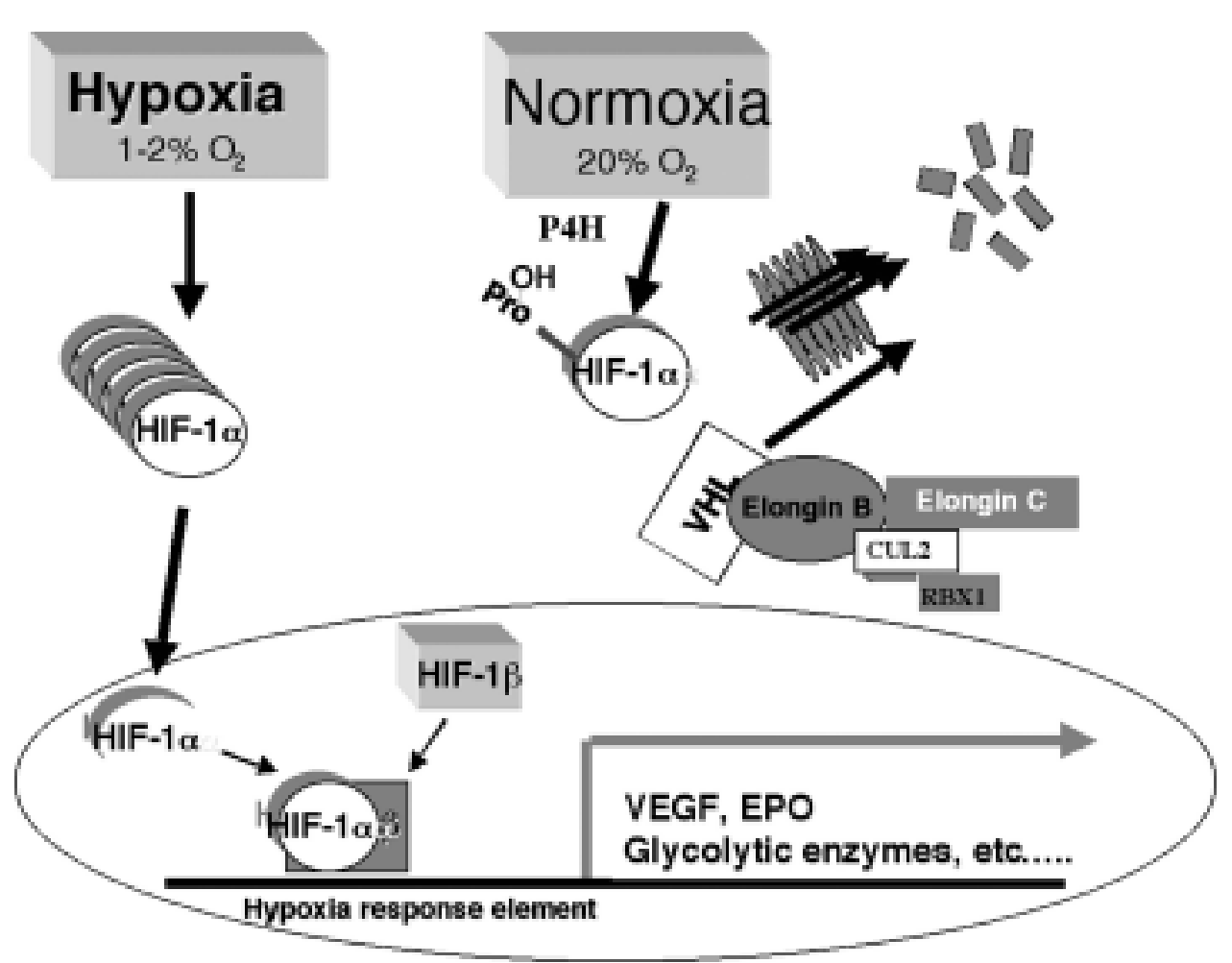

FIG. 4. Schematic representation of hypoxic control of HIF-1 $\alpha$ regulation and downstream HIF-1 $\alpha$ activity. The HIF1 is composed of two heterodimeric subunits, HIF- $1 \alpha$ and HIF-1 $\beta$, which are constitutively expressed. Under normoxic conditions, HIF-1 $\alpha$ undergoes proteasomal degradation by a mechanism that involves hydroxylation of proline residues on HIF- $1 \alpha$ by prolyl-4 hydroxylases and subsequent ubiquitination by the VHL protein E3 ubiquitin ligase system. Under hypoxic conditions, HIF- $1 \alpha$ is stabilized and heterodimerizes with HIF-1 $\beta$ to regulate transcription of downstream genes. $\mathrm{EPO}=$ erythropoietin.

detected under these conditions ${ }^{66}$ because of regulation by two independent mechanisms. The first involves hydroxylation of proline residues, which leads to proteasomal degradation mediated by the VHL protein. ${ }^{26,28,62,146}$ The second involves hydroxylation of an asparagine, which inhibits interaction between HIF-1 and the nuclear coactivator $\mathrm{CBP} / \mathrm{p} 300{ }^{20,57,89}$ Under conditions of hypoxia (1-2\% $\mathrm{O}_{2}$ ), these regulatory mechanisms are inhibited and HIF-1 activates HREs, which induce transcription of a number of genes that help the cell "cope" with low $\mathrm{O}_{2}$ conditions (Fig. 4). ${ }^{18,61,63,82,132,157}$ Hundreds of genes are responsive to either the HIF system or hypoxia. ${ }^{81,109,161}$ In addition to VEGF, other well-known HRMs include erythropoietin, glucose transporter-1, carbonic anhydrase IX, enolase, lactate dehydrogenase, tyrosine hydroxylase, aldolase A, phosphoglycerate kinase, transferrin and its receptor, and certain growth factors. ${ }^{20,73,81,133}$

\section{Tumor Growth and HRMs}

Constitutive expression of HIF-1 $\alpha$ has been detected in the cancer cells found in the hereditary syndrome VHL disease, ${ }^{79,98,119,165}$ and restoration of wild-type VHL protein returns HIF- $1 \alpha$ regulation. ${ }^{78,91}$ Given the importance of the VHL protein in HIF-1 regulation, it is not surprising that VHL disease is characterized by highly vascularized tumors. Most GBMs do not have somatic mutations of the
$V H L$ tumor suppressor gene, ${ }^{70}$ but alterations of components of the VHL-mediated HIF-1 $\alpha$ degradation pathways are plausible. In addition to $V H L$, other tumor suppressor genes, oncogenes, and growth factors have been reported to affect HIF-1 function. . $7,36,65,92,120,147,164,166^{2}$

Tumors derived from cells with HIF-1 $\alpha$ knockout show decreased cell growth in vivo and in vitro. ${ }^{25,90,127,128}$ Also, HIF- $1 \alpha$ is expressed even in normoxic conditions in human cancers like prostate, ${ }^{165}$ squamous cell, ${ }^{8}$ lung, ${ }^{153}$ breast,,$^{17,83}$ bladder, ${ }^{68}$ and pancreatic cancers. ${ }^{5}$ Overexpression of HIF-1 $\alpha$ is associated with more aggressive tumor grade, tumor invasion, resistance to radiation therapy, metastatic potential, and a worse prognosis. , $^{3,2,16,17,103,109 \text {, }}$ ${ }_{123,140}$ The expression of other HRMs and their association with cancer is less studied, although carbonic anhydrase IX and glucose transporter-1 expression reportedly correlates with poor response to adjuvant treatments. $30,108,139$

In higher-grade brain tumors, HRMs seem to be overexpressed (unpublished data). ${ }^{138,152,163}$ Our data from the study of 175 gliomas suggest that high-grade gliomas are more likely to be immunohistochemically positive for HIF-1 $\alpha$, VEGF, glucose transporter-1, and carbonic anhydrase IX than are low-grade tumors $(p=0.0001$ by chisquare testing; (RL Jensen, et al., in press). The expression of HIF-1 $\alpha$ does not seem to be confined to perinecrotic areas (Fig. 5). Increased expression of HRMs in highgrade tumors was confirmed by Western blot analysis performed at the time of surgery on protein extracts from 


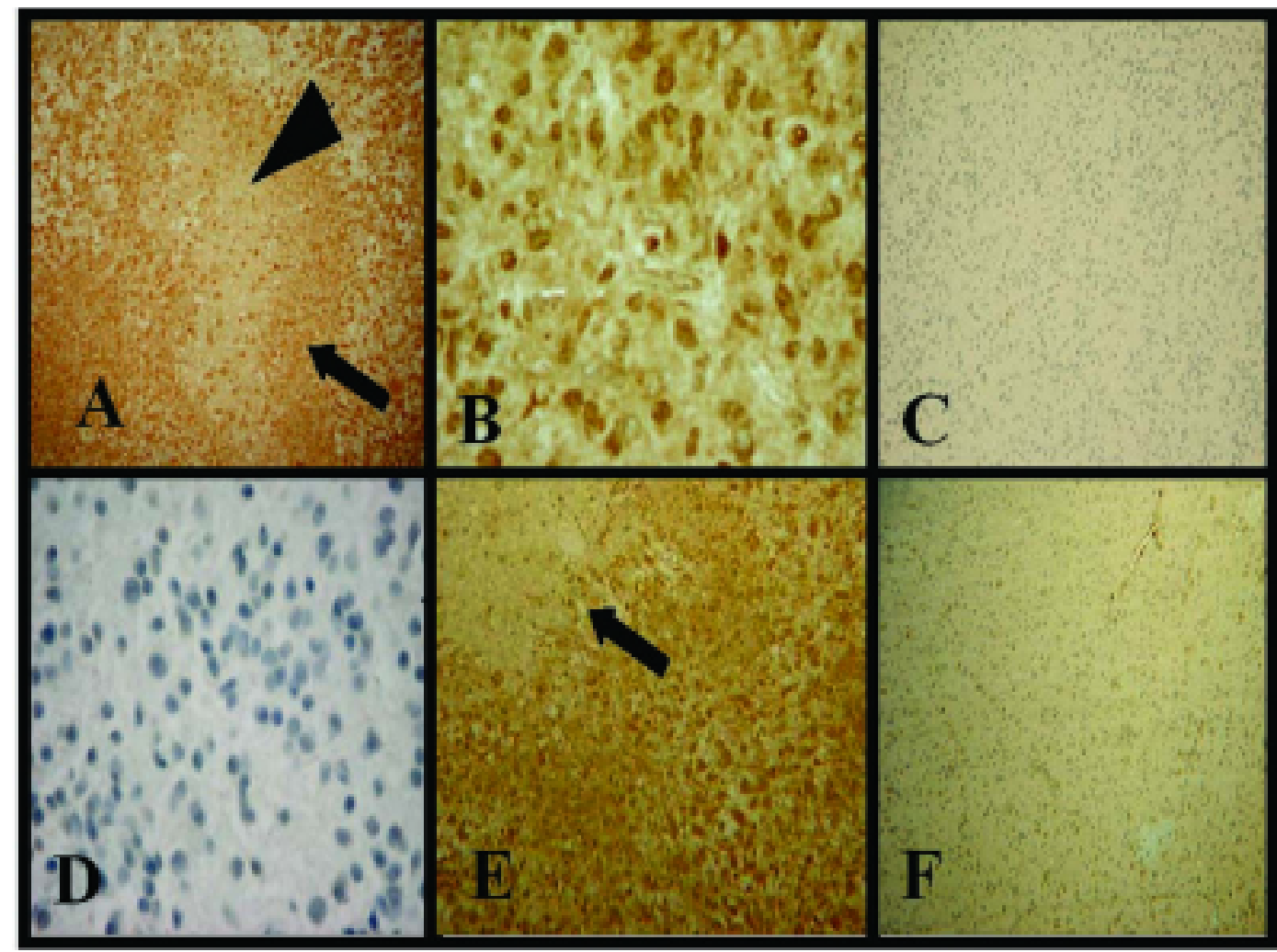

FIG. 5. Photomicrographs showing HIF-1 $\alpha$ and VEGF immunohistochemical findings. A: Tissue from a GBM prepared with immunohistochemical stain for HIF-1 (anti-HIF-1 $\alpha$ monoclonal antibody; Novus Biologicals, Littleton, CO), with 3', 3'-diaminobenzidine tetrahydrochloride as the developing substrate and toluidine blue as the counterstain. Sections demonstrate necrotic areas (arrowhead) with pseudopalisading cells (arrow) surrounding the necrotic areas. The HIF-1 $\alpha$ nuclear staining is strong throughout, not confined to perinecrotic regions. B: Tissue from a GBM showing strong nuclear staining for HIF-1 $\alpha$ throughout. $\quad$ C: Tissue from an LGA negative for HIF-1 $\alpha$. D: Tissue from a GBM (negative control; nonimmune serum substituted for antibody) for HIF- $1 \alpha$ showing no nuclear staining. E: Tissue from a GBM positive for VEGF. Section showing necrotic area (arrow) and strong VEGF expression. F: Tissue from an LGA negative for VEGF in a specimen prepared using same technique as in other examples in this figure. Original magnifications $\times 10(\mathrm{~A}, \mathrm{C}, \mathrm{E}$, and $\mathrm{F}) ; \times 40(\mathrm{~B}$ and $\mathrm{D})$.

human brain tumors (Fig. 6). Benign tumors such as meningiomas, vestibular schwannomas, and endolymphatic sac tumors were included with the various grades of glioma tumors for comparison. A correlation has been suggested between brain tumor grade, vascularity, and HIF-1 $\alpha$ expression, based on a small series of brain tumors. ${ }^{163}$

Glioma cell lines in culture express HRMs in response to hypoxic conditions (RL Jensen, et al., in press). ${ }^{40,74,81,166}$ Our data suggest that HIF- $1 \alpha$ is expressed even under normoxic conditions and that the hypoxic response is exaggerated in a number of GBM cell lines (RL Jensen, et al., in press), especially compared with more benign intracranial tumors (Fig. 7).

One unanswered question is whether HRM overexpression is simply a result of hypoxic stimulation. Colocalization of HIF-1 $\alpha$ expression and pimonidazole staining of U87 glioma cell lines have been demonstrated in vitro but not in tumor xenograft experiments. ${ }^{154,155}$ The expression of carbonic anhydrase IX and glucose transporter-1 is inversely distributed relative to vascular perfusion and correlates with polarographic $\mathrm{O}_{2}$ microelectrodes and pi- monidazole staining $4,86,99,108,160$ and with HIF-1 $\alpha$ expression, but there is debate over which "hypoxia marker" is the best. ${ }^{4,21}$ There are also concerns that HRM expression represents a real-time marker of hypoxia (that is, quick changes of cellular levels of HIF- $1 \alpha$ depending on the cellular $\mathrm{O}_{2}$ ), whereas biochemical markers of hypoxia bind to hypoxic tissues as a function of drug availability and tissue oxygenation and more likely represent cumulative or "historic" cellular hypoxia. ${ }^{155}$

\section{Hypoxia Response Element-Controlled Cancer Treatments}

A fundamental problem for cancer therapy is the lack of a tumor-selective delivery system. One approach to overcome this, at least in part, is to develop tumor-specific gene expression systems. ${ }^{136}$ An HRE is a short segment of nucleotides within a gene's promoter region that is recognized by transcription factors of the HIF family. The HREs from mouse phosphoglycerate kinase and human $V E G F$ or erythropoietin genes have been used to control 
the expression of marker and therapeutic genes in vitro and in vivo. ${ }^{11,123,124,135}$ Multimerized HREs coupled to minimal viral promoters have increased the efficiency of these systems. ${ }^{15,136}$ This approach has been used to increase apoptosis, produce an enzyme necessary for prodrug activation, and rescue postischemic neurons. ${ }^{15,23,124,136,137}$

Post and Van Meir ${ }^{106}$ have developed novel HIF-activated systems for cancer therapy, including a bidirectional hypoxia/HIF-responsive expression vector to target gene expression to hypoxic cells. They showed that these vectors have moderate to high inducibility at $1 \% \mathrm{O}_{2}$ but maintain tight regulation under normoxic conditions. With this system, they have produced a conditionally replicative oncolytic virus that can specifically lyse hypoxic tumor cells. ${ }^{107}$

In our laboratory, we have used RNA interference technology to target expression of HIF-1 (RL Jensen, unpublished data). We are working to adapt this technology to be under the control of hypoxic stimulation. The RNA interference is triggered by double-stranded RNA in a cell and results in the rapid destruction of messenger RNA that contains an identical or nearly identical sequence. ${ }^{37,54} \mathrm{Sev}-$ eral reports describe successful gene inhibition in mammalian cells that has been achieved with this technique. $22,24,35,93$ The ability to induce RNA interference from stably integrated plasmids or virus-producing shRNAs has been demonstrated in vitro and in vivo. ${ }^{56,95,102,125}$ Using this approach, $p 53$ gene silencing was accomplished in breast and lung carcinoma cell lines by using adenovirus-delivered siRNA. ${ }^{134}$

We have designed siRNAs for HIF- $1 \alpha$ by searching the coding sequence of HIF- $1 \alpha$ for two adenines followed by 19 nucleotides that had a GC content of less than $45 \%$ and did not contain more than three thymines or adenines in a row. These sequences were tested for possible homology to other human and mouse genes with the Basic Local Alignment Search Tool (http://www.ncbi.nlm.nih.gov/ BLAST). Four potential siRNA sequences were selected, and siRNA was prepared using a Silencer siRNA Construction Kit (Ambion, Inc., Austin, TX). Two DNA primers that contain the sense and antisense siRNA sequence and a short sequence complementary to the T7 Klenow DNA polymerase promoter were annealed and filled in with separate reactions. The T7 polymerase is used for in vitro transcription of the sense and antisense templates, which are then annealed and treated with RNase to digest the GGG overhangs left by T7 polymerase. The product is a 19-nucleotide double-stranded RNA with a UU overhang on each end. A negative control was designed by randomizing the sequence of one of the siRNAs and checking for nonhomology to any human or mouse gene by using the Basic Local Alignment Search Tool.

These constructs were tested for inhibition of HIF-1 activity and VEGF secretion (data not shown). To study stable HIF-1 $\alpha$ supression, the pSilencer 2.1 U6-hygro plasmid (Ambion, Inc.) was used to express an shRNA that was controlled via the U6 promoter. Two DNA oligonucleotides containing the sense and antisense siRNA sequences separated by a short loop sequence and having Bam HI- and HindIII-compatible overhanging ends were annealed and ligated into the linearized pSilencer plasmid. Two siRNA sequences that were found to best suppress HIF-1 $\alpha$ transiently were used, along with the negative control. U-251 cells were transfected with

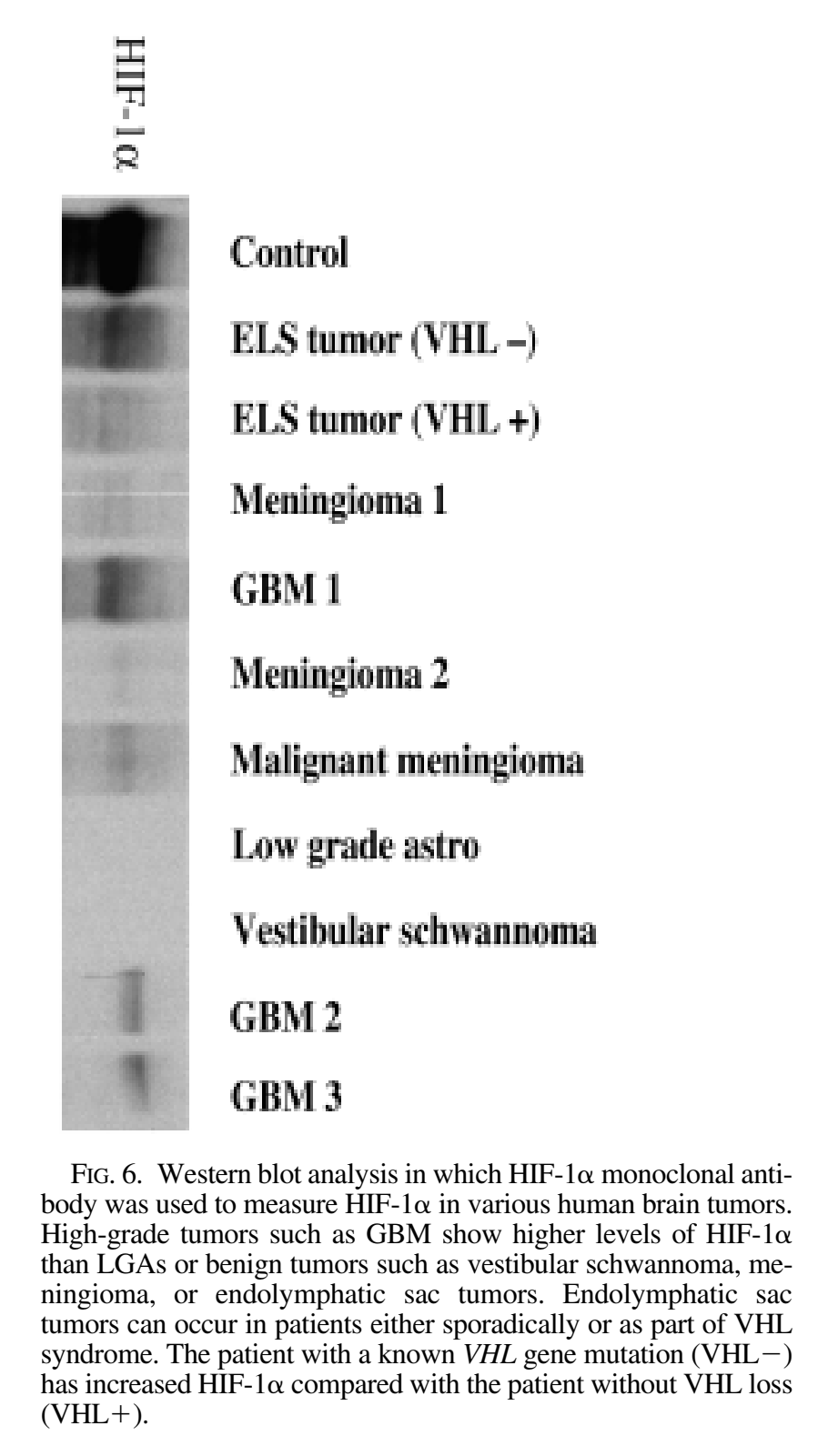

Fugene transfection reagent (Roche, Nutley, NJ), and transfectants were selected by hygromycin exposure. Stable transfectants were isolated using dilutional cloning and individual clones were tested for VEGF activity to find cell lines with various levels of HIF-1 inhibition (Fig. 8a). In a similar fashion, the same shRNA constructs were transfected into U251 glioma cell lines that were stably transfected with a luciferase reporter plasmid under the control of an HRE to test HIF-1 activity inhibition directly (Fig. 8b). All cell lines demonstrate various degrees of decreased VEGF secretion and HIF-1 expression under normoxic and hypoxic conditions (Student t-test, $\mathrm{p}<$ 0.05). However, clones such as RT21 appear to have more HIF-1 inhibition, making them especially interesting for further testing, including in vivo growth measurements, which will be published shortly. We plan to place this expression vector under the control of an HRE to allow for selective targeting of hypoxic cells with specific molecular targets. 

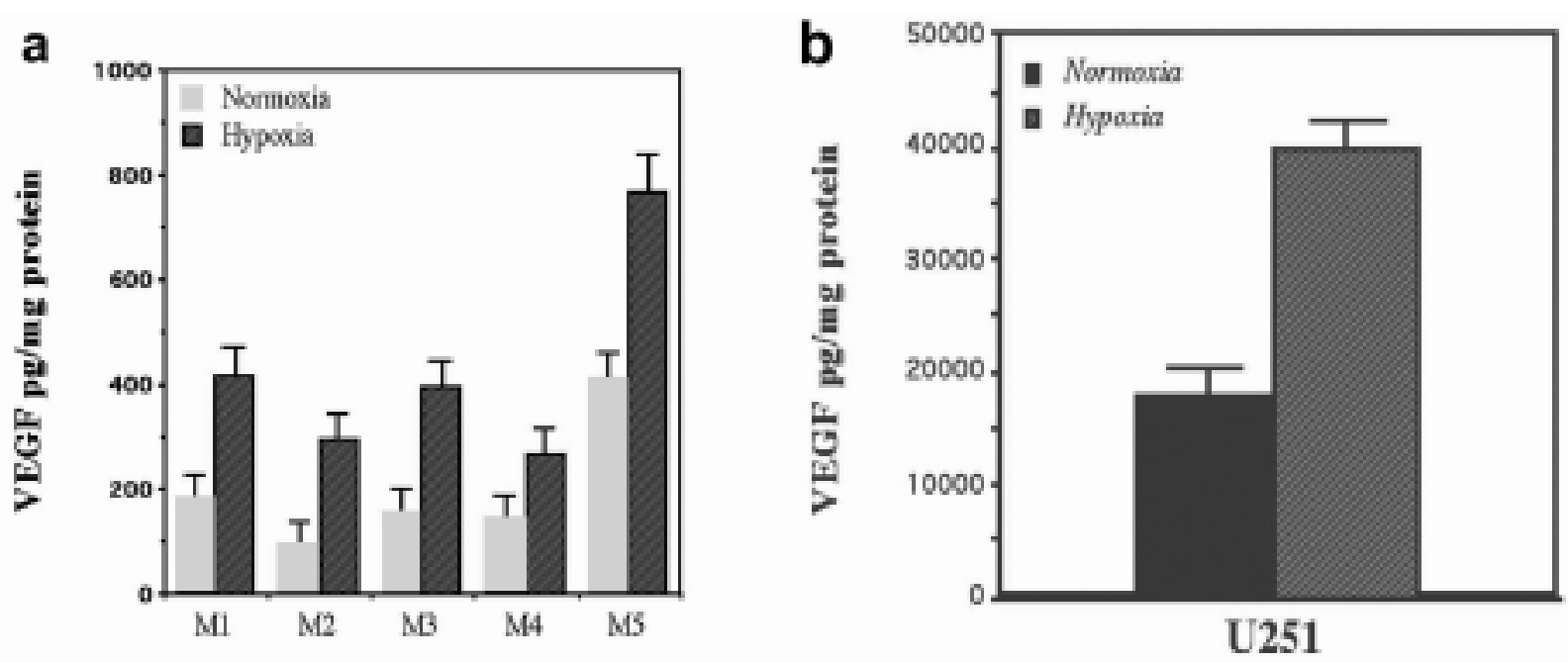

\section{Meningiomas}

FIG. 7. Bar graphs showing VEGF secretion in U251 GBM cell line and primary meningioma cultures measured under conditions of normoxia or hypoxia. Media taken from culture dishes growing each cell line were examined using enzyme-linked immunosorbent assay for VEGF protein and normalized to total protein in the media. Baseline VEGF production is much higher in the U251glioma cell line (b) than in each of the five meningioma cell cultures (M1-5) (a) under normoxic and hypoxic conditions. Note the 100-fold difference in the axis between each plot. All cell lines demonstrate increased VEGF secretion after 24 hours of hypoxia (Student t-test, $\mathrm{p}<0.05$ ).

a

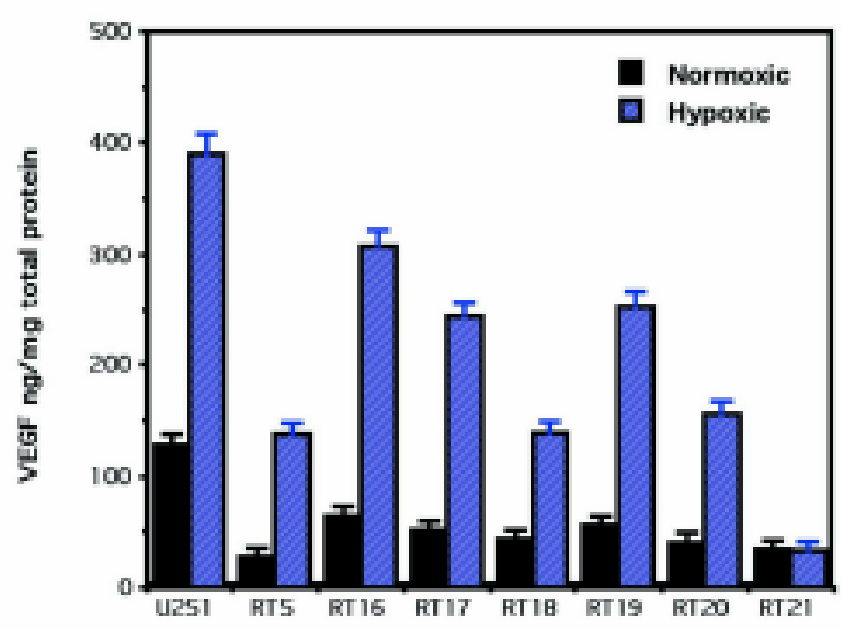

b

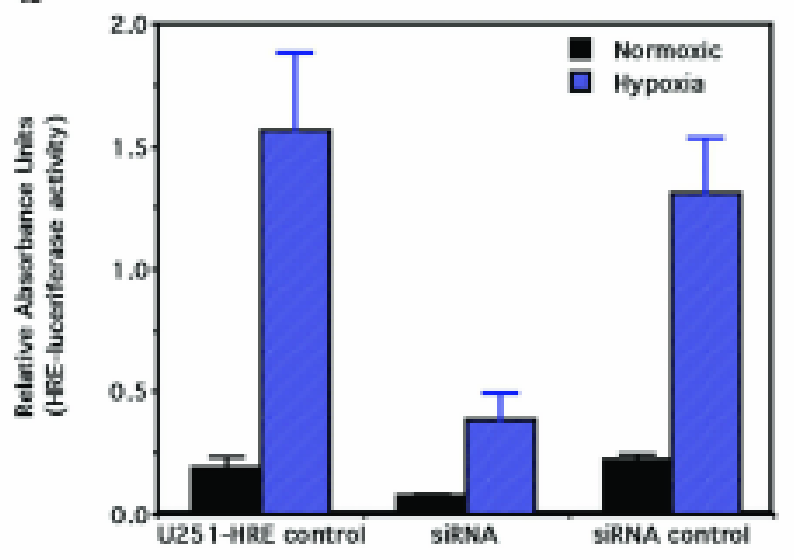

FIG. 8. Bar graph showing transfected U-251 cell lines. a: The U-251 cells were transfected with anti-HIF-1 siRNAexpressing plasmids. Transfectants were selected by hygromycin exposure. Stable transfectants were isolated with dilutional cloning, and individual clones were tested for VEGF activity to find cell lines with various levels of HIF-1 inhibition. b: In a similar fashion, the same shRNA constructs were transfected into a U251 glioma cell line stably transfected with a luciferase reporter plasmid under the control of an HRE. This allows for the direct testing of HIF-1 activity inhibition. All cell lines demonstrate various degrees of decreased VEGF secretion and HIF-1 expression under normoxic and hypoxic conditions (Student t-test, $\mathrm{p}<0.05$ ). However, clones such as RT21 appear to have more HIF-1 inhibition, making them especially interesting for further testing, including in vivo growth measurements. 


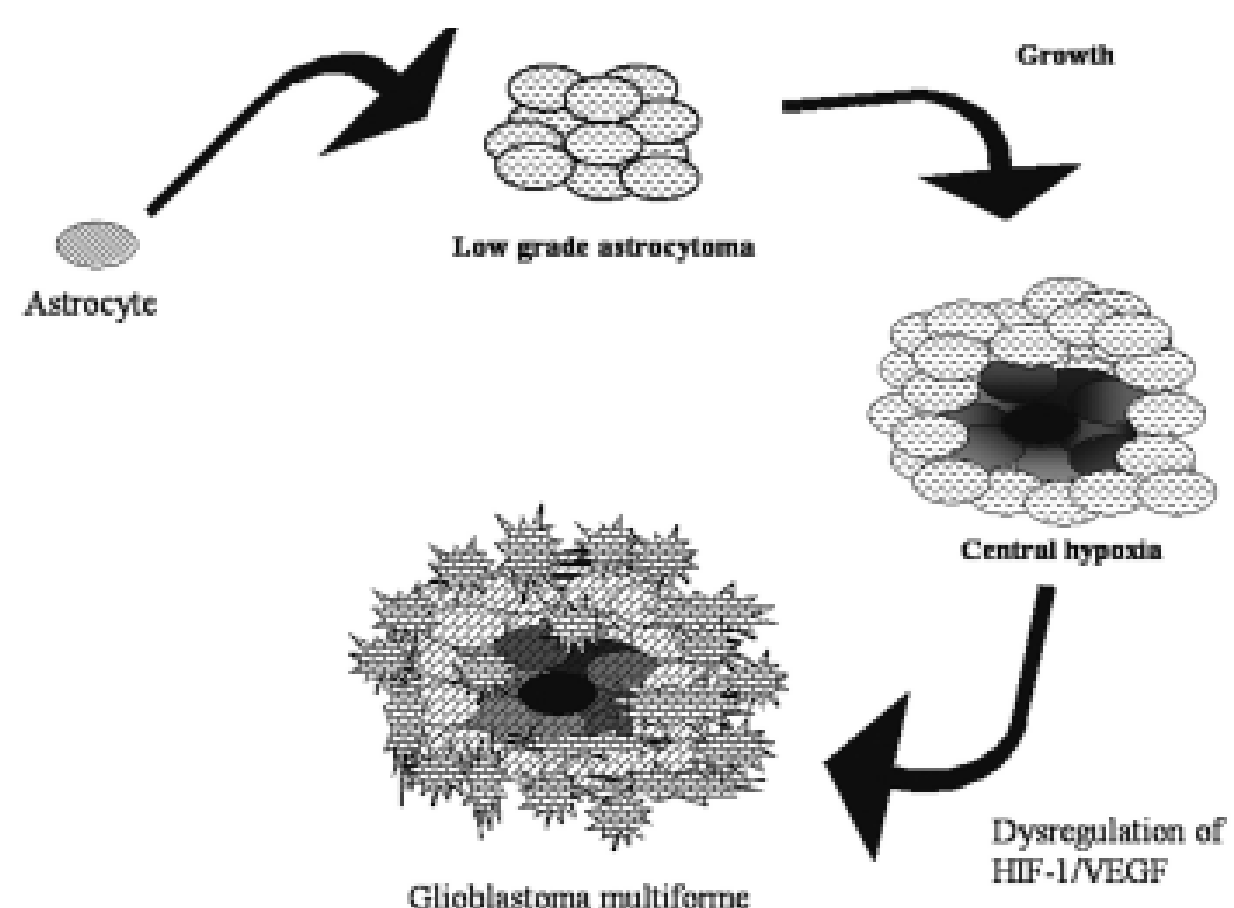

FIG. 9. Diagram illustrating the hypothesis presented in this paper. The transition from a low-grade glioma to GBM involves dysregulation of HIF-1 $\alpha$ triggered by initial tumor hypoxia or the clonal selection of cells with increased HIF$1 \alpha$ activity activated by nonhypoxic mechanisms. This occurs directly through HIF-1 $\alpha$ activity or indirectly through VEGF-mediated angiogenesis. This results in subsequent angiogenesis, endovascular proliferation, vascular permeability, peritumoral edema, and tumor invasion.

\section{Conclusions}

We hypothesize that the transformation of LGA to GBM is produced by hypoxia-induced phenotypic changes and subsequent clonal selection of cells that overexpress HRMs, such as HIF-1 $\alpha$. In this model, intratumoral hypoxia causes genetic changes (oncogene activation or tumor suppressor gene inactivation) and produces a microenvironment that selects for cells of a more aggressive phenotype (Fig. 9). As reviewed earlier, there is convincing evidence that HRMs such as HIF- $1 \alpha$, VEGF, carbonic anhydrase IX, or glucose transporter-1, may play a role in the tumorigenesis and angiogenesis of a number of malignancies, but their role is unclear in the case of malignant gliomas.

\section{References}

1. Abramovitch R, Dafni H, Smouha E, et al: In vivo prediction of vascular susceptibility to vascular susceptibility endothelial growth factor withdrawal. Magnetic resonance imaging of C6 rat glioma in nude mice. Cancer Res 59:5012-5016, 1999

2. Abramovitch R, Frenkiel D, Neeman M: Analysis of subcutaneous angiogenesis by gradient echo magnetic resonance imaging. Magn Reson Med 39:813-824, 1998

3. Aebersold DM, Burri P, Beer KT, et al: Expression of hypoxiainducible factor- $1 \alpha$ A novel predictive and prognostic parameter in the radiotherapy of oropharyngeal cancer. Cancer Res 61:2911-2916, 2001

4. Airley RE, Loncaster J, Raleigh JA, et al: GLUT-1 and CAIX as intrinsic markers of hypoxia in carcinoma of the cervix: relationship to pimonidazole binding. Int J Cancer 104:85-91, 2003
5. Akakura N, Kobayashi M, Horiuchi I, et al: Constitutive expression of hypoxia-inducible factor- $1 \alpha$ renders pancreatic cancer cells resistant to apoptosis induced by hypoxia and nutrient deprivation. Cancer Res 61:6548-6554, 2001

6. Alger JR, Frank JA, Bizzi A, et al: Metabolism of human gliomas: assessment with H-1 MR spectroscopy and F-18 fluorodeoxyglucose PET. Radiology 177:633-641, 1990

7. Arteel GE, Thurman RG, Raleigh JA: Reductive metabolism of the hypoxia marker pimonidazole is regulated by oxygen tension independent of the pyridine nucleotide redox state. Eur $\mathbf{J}$ Biochem 253:743-750, 1998

8. Beasley NJ, Leek R, Alam M, et al: Hypoxia-inducible factors HIF- $1 \alpha$ and HIF- $2 \alpha$ in head and neck cancer. Relationship to tumor biology and treatment outcome in surgically resected patients. Cancer Res 62:2493-2497, 2002

9. Bentzen L, Keiding S, Nordsmark M, et al: Tumour oxygenation assessed by ${ }^{18} \mathrm{~F}$-fluoromisonidazole PET and polarographic needle electrodes in human soft tissue tumors. Radiother Oncol 67:339-344, 2003

10. Bhujwalla ZM, Artemov D, Natarajan K, et al: Vascular differences detected by MRI for metastatic versus nonmetastatic breast and prostate cancer xenografts. Neoplasia 3:143-153, 2001

11. Binley K, Iqball S, Kingsman A, et al: An adenoviral vector regulated by hypoxia for the treatment of ischaemic disease and cancer. Gene Ther 6:1721-1727, 1999

12. Birner P, Schindl M, Obermair A, et al: Overexpression of hypoxia-inducible factor 1alpha is a marker for an unfavorable prognosis in early-stage invasive cervical cancer. Cancer Res 60:4693-4696, 2000

13. Blankenberg FG, Eckelman WC, Strauss HW, et al: Role of radionuclide imaging in trials of antiangiogenic therapy. Acad Radiol 7:851-867, 2000 
14. Blasberg RG, Kobayashi T, Horowitz M, et al: Regional blood flow in ethylnitrosourea-induced brain tumors. Ann Neurol 14:189-201, 1983

15. Boast K, Binley K, Iqball S, et al: Characterization of physiologically regulated vectors for the treatment of ischemic disease. Hum Gene Ther 10:2197-2208, 1999

16. Bos R, van der Groep P, Greijer AE, et al: Levels of hypoxiainducible factor- $1 \alpha$ independently predict prognosis in patients with lymph node negative breast carcinoma. Cancer 97:1573-1581, 2003

17. Bos R, Zhong H, Hanrahan CF, et al: Levels of hypoxiainducible factor-1 alpha during breast carcinogenesis. J Natl Cancer Inst 93:309-314, 2001

18. Brahimi-Horn C, Berra E, Pouysségur J: Hypoxia: the tumor's gateway to progression along the angiogenic pathway. Trends Cell Biol 11: S32-S36, 2001

19. Brasch R, Pham C, Shames D, et al: Assessing tumor angiogenesis using macromolecular MR imaging contrast media. J Magn Reson Imaging 7:68-74, 1997

20. Brat DJ, Mapstone TB: Malignant glioma physiology: cellular response to hypoxia and its role in tumor progression. Ann Intern Med 138:659-668, 2003

21. Brown JM, Le QT: Tumor hypoxia is important in radiotherapy, but how should we measure it? Int J Radiat Oncol Biol Phys 54:1299-1301, 2002

22. Brummelkamp TR, Bernards R, Agami R: A system for stable expression of short interfering RNAs in mammalian cells. Science 296:550-553, 2002

23. Cao YJ, Shibata T, Rainov NG: Hypoxia-inducible transgene expression in differentiated human NT2N neurons-a cell culture model for gene therapy of postischemic neuronal loss. Gene Ther 8:1357-1362, 2001

24. Caplen NJ, Parrish S, Imani F, et al: Specific inhibition of gene expression by small double-stranded RNAs in invertebrate and vertebrate systems. Proc Natl Acad Sci U S A 98:9742-9747, 2001

25. Carmeliet P, Dor Y, Herbert JM, et al: Role of HIF-1 $\alpha$ in hypoxia-mediated apoptosis, cell proliferation and tumor angiogenesis. Nature 394:485-490, 1998

26. Cho S, Choi YJ, Kim JM, et al: Binding and regulation of HIF$1 \alpha$ by a subunit of the proteasome complex, PSMA7. FEBS Lett 498:62-66, 2001

27. Chun YS, Choi E, Kim TY, et al: A dominant-negative isoform lacking exons 11 and 12 of the human hypoxia-inducible factor-1 $\alpha$ gene. Biochem J 362:71-79, 2002

28. Cockman ME, Masson N, Mole DR, et al: Hypoxia inducible factor- $\alpha$ binding and ubiquitylation by the von Hippel-Lindau tumor suppressor protein. J Biol Chem 275:25733-25741, 2000

29. Collingridge DR, Piepmeier JM, Rockwell S, et al: Polarographic measurements of oxygen tension in human glioma and surrounding peritumoral brain tissue. Radiother Oncol 53:127-131, 1999

30. Cooper R, Sarioglu S, Sokmen S, et al: Glucose transporter-1 (GLUT-1): a potential marker of prognosis in rectal carcinoma? Br J Cancer 89:870-876, 2003

31. Cuvier C, Jang A, Hill RP: Exposure to hypoxia, glucose starvation and acidosis: effect on invasive capacity of murine tumor cells and correlation with cathepsin $(\mathrm{L}+\mathrm{B})$ secretion. Clin Exp Metastasis 15:19-25, 1997

32. Daldrup H, Shames DM, Wendland M, et al: Correlation of dynamic contrast-enhanced MR imaging with histologic tumor grade: comparison of macromolecular and small-molecular contrast media. AJR Am J Roentgenol 171:941-949, 1998

33. Dehdashti F, Grigsby PW, Mintun MA, et al: Assessing tumor hypoxia in cervical cancer by positron emission tomography with ${ }^{60} \mathrm{Cu}$-ATSM: relationship to therapeutic response-a preliminary report. Int J Radiat Oncol Biol Phys 55:1233-1238, 2003
34. DeSouza BX, Alger JR, Frank JA, et al: Metabolism of human gliomas: assessment with H-1 MR spectroscopy and F-18 fluorodeoxyglucose PET. Radiology 177:633-641, 1990

35. Elbashir SM, Harborth J, Lendeckel W, et al: Duplexes of 21nucleotide RNAs mediate RNA interference in cultured mammalian cells. Nature 411:494-498, 2001

36. Feldser D, Agani F, Iyer NV, et al: Reciprocal positive regulation of hypoxia-inducible factor $1 \alpha$ and insulin-like growth factor 2. Cancer Res 59:3915-3918, 1999

37. Fire A, Xu S, Montgomery MK, et al: Potent and specific genetic interference by double-stranded RNA in Caenorhabditis elegans. Nature 391:806-811, 1998

38. Fisher MJ, Adamson PC: Anti-angiogenic agents for the treatment of brain tumors. Neuroimaging Clin N Am 12:477-499, 2002

39. Fujibayashi Y, Taniuchi H, Yonekura Y, et al: Copper-62aTSM: a new hypoxia imaging agent with high membrane permeability and low redox potential. J Nucl Med 38:1155-1160, 1997

40. Gaddipati JP, Madhavan S, Sidhu GS, et al: Picroliv—a natural product protects cells and regulates the gene expression during hypoxia/reoxygenation. Mol Cell Biochem 194:271-281, 1999

41. Gatenby RA, Kessler HB, Rosenblum JS, et al: Oxygen distribution in squamous cell carcinoma metastases and its relationship to outcome of radiation therapy. Int J Radiat Oncol Biol Phys 14:831-838, 1988

42. Giaccia AJ: Hypoxic stress proteins: survival of the fittest. Semin Radiat Oncol 6:46-58, 1996

43. Gilhuis HJ, Bernse HJJA, Jeuken JWM, et al: The relationship between genetic aberrations as detected by comparative genomic hybridization and vascularization in glioblastoma xenografts. J Neurooncol 51:121-127, 2001

44. Go KG, Kamman RL, Mooyaart EL, et al: Localised proton spectroscopy and spectroscopic imaging in cerebral gliomas, with comparison to positron emission tomography. Neuroradiology 37:198-206, 1995

45. Goldman CK, Bharara S, Palmer CA, et al: Brain edema in meningiomas is associated with increased vascular endothelial growth factor expression. Neurosurgery 40:1269-1277, 1997

46. Gossmann A, Okuhata Y, Shames DM, et al: Prostate cancer tumor grade differentiation with dynamic contrast-enhanced MR imaging in the rat: comparison of macromolecular and small-molecular contrast media-preliminary experience. Radiology 213:265-272, 1999

47. Graeber TG, Osmanian C, Jacks T, et al: Hypoxia-mediated selection of cells with diminished apoptotic potential in solid tumors. Nature 379:88-91, 1996

48. Graham CH, Forsdike J, Fitzgerald CJ, et al: Hypoxia-mediated stimulation of carcinoma cell invasiveness via upregulation of urokinase receptor expression. Int J Cancer 80:617-623, 1999

49. Griffiths JR, Taylor NJ, Howe FA, et al: The response of human tumors to carbogen breathing, monitored by gradient-recalled echo magnetic resonance imaging. Int J Radiat Oncol Biol Phys 39:697-701, 1997

50. Groothuis DR, Pasternak JF, Fischer JM, et al: Regional measurements of blood flow in experimental RG-2 rat gliomas. Cancer Res 43:3362-3367, 1983

51. Groshar D, McEwan AJ, Parliament MB, et al: Imaging tumor hypoxia and tumor perfusion. J Nucl Med 34:885-888, 1993

52. Hammoud MA, Sawaya R, Shi W, et al: Prognostic significance of preoperative MRI scans in glioblastoma multiforme. J Neurooncol 27:65-73, 1996

53. Hanahan D, Folkman J: Patterns and emerging mechanisms of the angiogenic switch during tumorigenesis. Cell 86:353-364, 1996

54. Hannon GJ: RNA interference. Nature 418:244-251, 2002

55. Helmlinger G, Yuan F, Dellian M, et al: Interstitial $\mathrm{pH}$ and $\mathrm{pO} 2$ gradients in solid tumors in vivo: high-resolution measurements reveal a lack of correlation. Nat Med 3:177-182, 1997 
56. Hemann MT, Fridman JS, Zilfou JT, et al: An epi-allelic series of p53 hypomorphs created by stable RNAi produces distinct tumor phenotypes in vivo. Nat Genet 33:396-400, 2003

57. Hewitson KS, McNeill LA, Riordan MV, et al: Hypoxiainducible factor (HIF) asparagine hydroxylase is identical to factor inhibiting HIF (FIH) and is related to the cupin structural family. J Biol Chem 277:26351-26355, 2002

58. Hockel M, Schlenger K, Aral B, et al: Association between tumor hypoxia and malignant progression in advanced cancer of the uterine cervix. Cancer Res 56:4509-4515, 1996

59. Hockel M, Schlenger K, Hockel S, et al: Tumor hypoxia in pelvic recurrences of cervical cancer. Int J Cancer 79: 365-369, 1998

60. Hossman KA, Bloink M: Blood flow and regulation of blood flow in experimental peritumoral edema. Stroke 12:211-217, 1981

61. Ivan M, Kondo K, Yang H, et al: HIFalpha targeted for VHLmediated destruction by proline hydroxylation: implications for $\mathrm{O}_{2}$ sensing. Science 292:464-468, 2001

62. Iwai K, Yamanaka K, Kamura T, et al: Identification of the von Hippel-Lindau tumor-suppressor protein as part of an active E3 ubiquitin ligase complex. Proc Natl Acad Sci U S A 96: 12436-12441, 1999

63. Jaakkola P, Mole DR, Tian YM, et al: Targeting of HIF- $\alpha$ to the von Hippel-Lindau ubiquitylation complex by $\mathrm{O}_{2}$-regulated prolyl hydroxylation. Science 292:468-472, 2001

64. Jain RK: Determinants of tumor blood flow: a review. Cancer Res 48:2641-2658, 1988

65. Jiang BH, Rue E, Wang GL, et al: Dimerization, DNA binding, and transactivation properties of hypoxia-inducible factor 1 . J Biol Chem 271:17771-17778, 1996

66. Jiang BH, Semenza GL, Bauer C, et al: Hypoxia-inducible factor 1 levels vary exponentially over a physiologically relevant range of $\mathrm{O}_{2}$ tension. Am J Physiol 271: C1172-C1180, 1996

67. Jogi A, Ora I, Nilsson H, et al: Hypoxia alters gene expression in human neuroblastoma cells toward an immature and neural crest-like phenotype. Proc Natl Acad Sci U S A 99: 7021-7026, 2002

68. Jones A, Fujiyama C, Blanche C, et al: Relation of vascular endothelial growth factor production to expression and regulation of hypoxia-inducible factor- $1 \alpha$ and hypoxia-inducible factor- $2 \alpha$ in human bladder tumors and cell lines. Clin Cancer Res 7:1263-1272, 2001

69. Kallinowski F, Zander R, Hoeckel M, et al: Tumor tissue oxygenation as evaluated by computerized- $\mathrm{pO}_{2}$-histography. Int J Radiat Oncol Biol Phys 19:953-961, 1990

70. Kanno H, Shuin T, Kondo K, et al: Somatic mutations of the von Hippel-Lindau tumor suppressor gene and loss of heterozygosity on chromosome $3 \mathrm{p}$ in human glial tumors. Cancer Res 57:1035-1038, 1997

71. Kayama T, Yoshimoto T, Fujimoto S, et al: Intratumoral oxygen pressure in malignant brain tumor. J Neurosurg 74:55-59, 1991

72. Kerbel RS, Viloria-Petit A, Okada F, et al: Establishing a link between oncogenes and tumor angiogenesis. Mol Med 4: 286-295, 1998

73. Kietzmann T, Krones-Herzig A, Jungermann K: Signaling cross-talk between hypoxia and glucose via hypoxia-inducible factor 1 and glucose response elements. Biochem Pharmacol 64:903-911, 2002

74. Kimura H, Weisz A, Kurashima Y, et al: Hypoxia response element of the human vascular endothelial growth factor gene mediates transcriptional regulation by nitric oxide: control of hypoxia-inducible factor-1 activity by nitric oxide. Blood 95: 189-197, 2000

75. Kleihues P, Louis DN, Scheithauer BW, et al: The WHO classification of tumors of the nervous system. J Neuropathol Exp Neurol 61:215-226, 2002

76. Knisely JP, Rockwell S: Importance of hypoxia in the biology and treatment of brain tumors. Neuroimaging Clin N Am 12: 525-536, 2002

77. Knopp EA, Cha S, Johnson G, et al: Glial neoplasms: dynamic contrast-enhanced $\mathrm{T}_{2}$-weighted MR imaging. Radiology 211: 791-798, 1999

78. Kondo K, Klco J, Nakamura E, et al: Inhibition of HIF is necessary for tumor suppression by the von Hippel-Lindau protein. Cancer Cell 1:237-246, 2002

79. Krieg M, Haas R, Brauch H, et al: Up-regulation of hypoxiainducible factors HIF-1 $\alpha$ and HIF-2 $\alpha$ under normoxic conditions in renal carcinoma cells by von Hippel-Lindau tumor suppressor gene loss of function. Oncogene 19:5435-5443, 2000

80. Lacroix M, Abi-Said D, Fourney DR, et al: A multivariate analysis of 416 patients with glioblastoma multiforme: prognosis, extent of resection, and survival. J Neurosurg 95:190-198, 2001

81. Lal A, Peters H, St Croix B, et al: Transcriptional response to hypoxia in human tumors. J Natl Cancer Inst 93:1337-1343, 2001

82. Lando D, Peet DJ, Whelan DA, et al: Asparagine hydroxylation of the HIF transactivation domain: a hypoxic switch. Science 295:858-861, 2002

83. Leek RD, Talks KL, Pezzella F, et al: Relation of hypoxiainducible factor-2 alpha (HIF-2 alpha) expression in tumor-infiltrative macrophages to tumor angiogenesis and the oxidative thymidine phosphorylase pathway in human breast cancer. Cancer Res 62:1326-1329, 2002

84. Lewis JS, McCarthy DW, McCarthy TJ, et al: Evaluation of $64 \mathrm{Cu}-\mathrm{ATSM}$ in vitro and in vivo in a hypoxic tumor model. $\mathbf{J}$ Nucl Med 40:177-183, 1999

85. Lewis JS, Sharp TL, Laforest R, et al: Tumor uptake of copperdiacetyl-bis $\left(N^{4}\right)$-methylthiosemicarbazone): effect of changes in tissue oxygenation. J Nucl Med 42:655-661, 2001

86. Loncaster JA, Harris AL, Davidson SE, et al: Carbonic anhydrase (CA IX) expression, a potential new intrinsic marker of hypoxia: correlations with tumor oxygen measurements and prognosis in locally advanced carcinoma of the cervix. Cancer Res 61:6394-6399, 2001

87. Lord EM, Harwell L, Koch CJ: Detection of hypoxic cells by monoclonal antibody recognizing 2-nitroimidazole adducts. Cancer Res 53:5721-5726, 1993

88. Louis DN, Gusella JF: A tiger behind many doors: multiple genetic pathways to malignant glioma. Trends Genet 11: 412-415, 1995

89. Mahon PC, Hirota K, Semenza GL: FIH-1: a novel protein that interacts with HIF-1 $\alpha$ and VHL to mediate repression of HIF-1 transcriptional activity. Genes Dev 15:2675-2686, 2001

90. Maxwell PH, Dachs GU, Gleadle JM, et al: Hypoxia-inducible factor-1 modulates gene expression in solid tumors and influences both angiogenesis and tumor growth. Proc Natl Acad Sci U S A 94:8104-8109, 1997

91. Maxwell PH, Wiesener MS, Chang GW, et al: The tumor suppressor protein VHL targets hypoxia-inducible factors for oxygen-dependent proteolysis. Nature 399:271-275, 1999

92. Mazure NM, Chen EY, Laderoute KR, et al: Induction of vascular endothelial growth factor by hypoxia is modulated by a phosphatidylinositol 3-kinase/Akt signaling pathway in Ha-rastransformed cells through a hypoxia inducible factor-1 transcriptional element. Blood 90:3322-3331, 1997

93. McCaffrey AP, Meuse L, Pham TTT, et al: Gene expression: RNA interference in adult mice. Nature 418:38-39, 2002

94. McDonald DM, Choyke PL: Imaging of angiogenesis: from microscope to clinic. Nat Med 9:713-725, 2003

95. Miyagishi M, Taira K: U6 promoter-driven siRNAs with four uridine 3' overhangs efficiently suppress targeted gene expression in mammalian cells. Nat Biotechnol 20:497-500, 2002

96. Moller-Hartmann W, Herminghaus S, Krings T, et al: Clinical application of proton magnetic resonance spectroscopy in the diagnosis of intracranial mass lesions. Neuroradiology 44: $371-381,2002$ 
97. Obata A, Yoshimi E, Waki A, et al: Retention mechanism of hypoxia selective nuclear imaging/radiotherapeutic agent cudiacetyl-bis(N4-methylthiosemicarbazone) (Cu-ATSM) in tumor cells. Ann Nucl Med 15:499-504, 2001

98. Ohh M, Park CW, Ivan M, et al: Ubiquitination of hypoxiainducible factor requires direct binding to the $\beta$-domain of the von Hippel-Lindau protein. Nat Cell Biol 2:423-427, 2000

99. Olive PL, Aquino-Parsons C, MacPhail SH, et al: Carbonic anhydrase 9 as an endogenous marker for hypoxic cells in cervical cancer. Cancer Res 61:8924-8929, 2001

100. Parliament MB, Franko AJ, Allalunis-Turner MJ, et al: Anomalous patterns of nitroimidazole binding adjacent to necrosis in human glioma xenografts: possible role of decreased oxygen consumption. Br J Cancer 75:311-318, 1997

101. Pathak AP, Schmainda KM, Ward BD, et al: MR-derived cerebral blood volume maps: issues regarding histological validation and assessment of tumor angiogenesis. Magn Reson Med 46:735-747, 2001

102. Paul CP, Good PD, Winer I, et al: Effective expression of small interfering RNA in human cells. Nat Biotechnol 20: 505-508, 2002

103. Pennacchietti S, Michieli P, Galluzzo M, et al: Hypoxia promotes invasive growth by transcriptional activation of the met protooncogene. Cancer Cell 3:347-361, 2003

104. Pham CD, Roberts TP, van Bruggen N, et al: Magnetic resonance imaging detects suppression of tumor vascular permeability after administration of antibody to vascular endothelial growth factor. Cancer Invest 16:225-230, 1998

105. Plate KH: Mechanisms of angiogenesis in the brain. J Neuropathol Exp Neurol 58:313-320, 1999

106. Post DE, Van Meir EG: Generation of bidirectional hypoxia/ HIF-responsive expression vectors to target gene expression to hypoxic cells. Gene Ther 8:1801-1807, 2001

107. Post DE, Van Meir EG: A novel hypoxia-inducible factor (HIF) activated oncolytic adenovirus for cancer therapy. Oncogene 22:2065-2072, 2003

108. Potter CPS, Harris AL: Diagnostic, prognostic and therapeutic implications of carbonic anhydrases in cancer. Br J Cancer 89:2-7, 2003

109. Pugh CW, Ratcliffe PJ: The von Hippel-Lindau tumor suppressor, hypoxia-inducible factor-1 (HIF-1) degradation, and cancer pathogenesis. Semin Cancer Biol 13:83-89, 2003

110. Rak J, Filmus J, Finkenzeller G, et al: Oncogenes as inducers of tumor angiogenesis. Cancer Metastasis Rev 14:263-277, 1995

111. Raleigh JA, Chou SC, Arteel GE, et al: Comparisons among pimonidazole binding, oxygen electrode measurements, and radiation response in $\mathrm{C} 3 \mathrm{H}$ mouse tumors. Radiat Res 151: 580-589, 1999

112. Raleigh JA, Chou SC, Calkins-Adams DP, et al: A clinical study of hypoxia and metallothionein protein expression in squamous cell carcinomas. Clin Cancer Res 6:855-862, 2000

113. Rampling R, Cruickshank G, Lewis AD, et al: Direct measurement of $\mathrm{pO} 2$ distribution and bioreductive enzymes in human malignant brain tumors. Int J Radiat Oncol Biol Phys 29:427-431, 1994

114. Rasey JS, Casciari JJ, Hofstrand PD, et al: Determining hypoxic fraction in a rat glioma by uptake of radiolabeled fluoromisonidazole. Radiat Res 153:84-92, 2000

115. Rasey JS, Hofstrand PD, Chin LK, et al: Characterization of $\left[{ }^{18} \mathrm{~F}\right]$ fluoroetanidazole, a new radiopharmaceutical for detecting tumor hypoxia. J Nucl Med 40:1072-1079, 1999

116. Rasey JS, Koh WJ, Evans ML, et al: Quantifying regional hypoxia in human tumors with positron emission tomography of $\left[{ }^{18} \mathrm{~F}\right]$ fluoromisonidazole: a pretherapy study of 37 patients. Int J Radiat Oncol Biol Phys 36:417-428, 1996

117. Raza SM, Lang FF, Aggarwal BB, et al: Necrosis and glio- blastoma: a friend or a foe? A review and a hypothesis. Neurosurgery 51:2-13, 2002

118. Rice GC, Hoy C, Schimke RT: Transient hypoxia enhances the frequency of dihydrofolate reductase gene amplification in Chinese hamster ovary cells. Proc Natl Acad Sci U S A 83:5978-5982, 1986

119. Richard DE, Berra E, Pouyssegur J: Angiogenesis: how a tumor adapts to hypoxia. Biochem Biophys Res Commun 266:718-722, 1999

120. Richard DE, Berra E, Pouyssegur J: Nonhypoxic pathway mediates the induction of hypoxia-inducible factor 1alpha in vascular smooth muscle cells. J Biol Chem 275:2676526771, 2000

121. Rijken PFJW, Bernsen HJJA, Peters JPW, et al: Spatial relationship between hypoxia and the (perfused) vascular network in a human glioma xenograft: a quantitative multi-parameter analysis. Int J Radiat Oncol Biol Phys 48:571-582, 2000

122. Rischin D, Peters L, Hicks R, et al: Phase I trial of concurrent tirapazamine, cisplatin, and radiotherapy in patients with advanced head and neck cancer. J Clin Oncol 19:535-542, 2001

123. Ruan H, Su H, Hu L, et al: A hypoxia-regulated adeno-associated virus vector for cancer-specific gene therapy. Neoplasia 3:255-263, 2001

124. Ruan H, Wang J, Hu L, et al: Killing of brain tumor cells by hypoxia-responsive element mediated expression of BAX. Neoplasia 1:431-437, 1999

125. Rubinson DA, Dillon CP, Kwiatkowski AV, et al: A lentivirus-based system to functionally silence genes in primary mammalian cells, stem cells and transgenic mice by RNA interference. Nat Genet 33:401-406, 2003 (Letter)

126. Russo CA, Weber TK, Volpe CM, et al: An anoxia inducible endonuclease and enhanced DNA breakage as contributors to genomic instability in cancer. Cancer Res 55:1122-1128, 1995

127. Ryan HE, Lo J, Johnson RS: HIF-1 alpha is required for solid tumor formation and embryonic vascularization. Embo J 17: 3005-3015, 1998

128. Ryan HE, Poloni M, McNulty W, et al: Hypoxia-inducible factor- $1 \alpha$ is a positive factor in solid tumor growth. Cancer Res 60:4010-4015, 2000

129. Sakata K, Kwok TT, Murphy BJ, et al: Hypoxia-induced drug resistance: comparison to P-glycoprotein-associated drug resistance. Br J Cancer 64:809-814, 1991

130. Sanna K, Rofstad EK: Hypoxia-induced resistance to doxorubicin and methotrexate in human melanoma cell lines in vitro. Int J Cancer 58:258-262, 1994

131. Seimiya H, Tanji M, Oh-hara T, et al: Hypoxia up-regulates telomerase activity via mitogen-activated protein kinase signaling in human solid tumor cells. Biochem Biophys Res Commun 260:365-370, 1999

132. Semenza GL: Regulation of mammalian $\mathrm{O}_{2}$ homeostasis by hypoxia-inducible factor 1. Annu Rev Cell Dev Biol 15: 551-578, 1999

133. Semenza GL: Physiology meets biophysics: visualizing the interaction of hypoxia-inducible factor $1 \alpha$ with p300 and CBP. Proc Natl Acad Sci U S A 99:11570-11572, 2002

134. Shen C, Buck AK, Liu X, et al: Gene silencing by adenovirus-delivered siRNA. FEBS Lett 539:111-114, 2003

135. Shibata T, Akiyama N, Noda M, et al: Enhancement of gene expression under hypoxic conditions using fragments of the human vascular endothelial growth factor and the erythropoietin genes. Int J Radiat Oncol Biol Phys 42:913-916, 1998

136. Shibata T, Giaccia AJ, Brown JM: Development of a hypoxia-responsive vector for tumor-specific gene therapy. Gene Ther 7:493-498, 2000

137. Shibata T, Giaccia AJ, Brown JM: Hypoxia-inducible regulation of a prodrug-activating enzyme for tumor-specific gene therapy. Neoplasia 4:40-48, 2002 
138. Sondergaard KL, Hilton DA, Penney M, et al: Expression of hypoxia-inducible factor $1 \alpha$ in tumors of patients with glioblastoma. Neuropathol Appl Neurobiol 28:210-217, 2002

139. Span PN, Bussink J, Manders P, et al: Carbonic anhydrase-9 expression levels and prognosis in human breast cancer: association with treatment outcome. Br J Cancer 89:271276, 2003

140. Staller P, Sulitkova J, Lisztwan J, et al: Chemokine receptor CXCR4 downregulated by von Hippel-Lindau tumor suppressor pVHL. Nature 425:307-311, 2003

141. Stoler DL, Anderson GR, Russo CA, et al: Anoxia-inducible endonuclease activity as a potential basis of the genomic instability of cancer cells. Cancer Res 52:4372-4378, 1992

142. Su MY, Najafi AA, Nalcioglu O: Regional comparison of tumor vascularity and permeability parameters measured by albumin-Gd-DTPA and Gd-DTPA. Magn Reson Med 34: 402-411, 1995

143. Sugahara T, Korogi Y, Tomiguchi S, et al: Posttherapeutic intraaxial brain tumor: the value of perfusion-sensitive contrast-enhanced MR imaging for differentiating tumor recurrence from nonneoplastic contrast-enhancing tissue. AJNR Am J Neuroradiol 21:901-909, 2000

144. Sundfor K, Lyng H, Rofstad EK: Tumour hypoxia and vascular density as predictors of metastasis in squamous cell carcinoma of the uterine cervix. Br J Cancer 78:822-827, 1998

145. Sutherland RM: Tumor hypoxia and gene expression: implications for malignant progression and therapy. Acta Oncol 37:567-574, 1998

146. Sutter CH, Laughner E, Semenza GL: Hypoxia-inducible factor $1 \alpha$ protein expression is controlled by oxygen-regulated ubiquitination that is disrupted by deletions and missense mutations. Proc Natl Acad Sci U S A 97:4748-4753, 2000

147. Tacchini L, Dansi P, Matteucci E, et al: Hepatocyte growth factor signalling stimulates hypoxia inducible factor-1 (HIF1) activity in HepG2 hepatoma cells. Carcinogenesis 22: 1363-1371, 2001

148. Tochon-Danguy HJ, Sachinidis JI, Chan F, et al: Imaging and quantitation of the hypoxic cell fraction of viable tumor in an animal model of intracerebral high grade glioma using $\left[{ }^{18} \mathrm{~F}\right]$ fluoromisonidazole (FMISO). Nucl Med Biol 29:191197,2002

149. Turetschek K, Roberts TP, Floyd E, et al: Tumor microvascular characterization using ultrasmall superparamagnetic iron oxide particles (USPIO) in an experimental breast cancer model. J Magn Reson Imaging 13:882-888, 2001

150. Vajkoczy P, Menger MD: Vascular microenvironment in gliomas. Cancer Treat Res 117:249-262, 2004

151. Valk PE, Mathis CA, Prados MD, et al: Hypoxia in human gliomas: demonstration by PET with fluorine-18-fluoromisonidazole. J Nucl Med 33:2133-2137, 1992

152. Vidal S, Horvath E, Kovacs K, et al: Expression of hypoxiainducible factor- $1 \alpha(\mathrm{HIF}-1 \alpha)$ in pituitary tumors. Histol Histopathol 18:679-686, 2003

153. Volm M, Koomagi R: Hypoxia-inducible factor (HIF-1) and its relationship to apoptosis and proliferation in lung cancer.
Anticancer Res 20:1527-1533, 2000

154. Vordermark D, Brown JM: Evaluation of hypoxia-inducible factor- $1 \alpha(\mathrm{HIF}-1 \alpha)$ as an intrinsic marker of tumor hypoxia in U87 MG human glioblastoma: in vitro and xenograft studies. Int J Radiat Oncol Biol Phys 56:1184-1193, 2003

155. Vukovic V, Haugland HK, Nicklee T, et al: Hypoxiainducible factor- $1 \alpha$ is an intrinsic marker for hypoxia in cervical cancer xenografts. Cancer Res 61:7394-7398, 2001

156. Walenta S, Wetterling M, Lehrke M, et al: High lactate levels predict likelihood of metastases, tumor recurrence, and restricted patient survival in human cervical cancers. Cancer Res 60:916-921, 2000

157. Wang GL, Jiang BH, Rue EA, et al: Hypoxia-inducible factor 1 is a basic-helix-loop-helix-PAS heterodimer regulated by cellular $\mathrm{O}_{2}$ tension. Proc Natl Acad Sci USA 92:5510-5514, 1995

158. Wijffels KIEM, Kaanders JHAM, Rijken PFJW, et al: Vascular architecture and hypoxic profiles in human head and neck squamous cell carcinomas. Br J Cancer 83:674-683, 2000

159. Wilson RE, Keng PC, Sutherland RM: Drug resistance in Chinese hamster ovary cells during recovery from severe hypoxia. J Natl Cancer Inst 81:1235-1240, 1989

160. Wykoff CC, Beasley NJ, Watson PH, et al: Hypoxia-inducible expression of tumor-associated carbonic anhydrases. Cancer Res 60:7075-7083, 2000

161. Wykoff CC, Pugh CW, Maxwell PH, et al: Identification of novel hypoxia dependent and independent target genes of the von Hippel-Lindau (VHL) tumor suppressor by mRNA differential expression profiling. Oncogene 19:6297-6305, 2000

162. Yetkin FZ, Mendelsohn D: Hypoxia imaging in brain tumors. Neuroimaging Clin N Am 12:537-552, 2002

163. Zagzag D, Zhong H, Scalzitti JM, et al: Expression of hypoxia-inducible factor $1 \alpha$ in brain tumors. Association with angiogenesis, invasion, and progression. Cancer 88: 2606-2618, 2000

164. Zelzer E, Levy Y, Kahana C, et al: Insulin induces transcription of target genes through the hypoxia-inducible factor HIF-1 $\alpha / A R N T$. Embo J 17:5085-5094, 1998

165. Zhong H, De Marzo AM, Laughner E, et al: Overexpression of hypoxia-inducible factor 1alpha in common human cancers and their metastases. Cancer Res 59:5830-5835, 1999

166. Zundel W, Schindler C, Haas-Kogan D, et al: Loss of PTEN facilitates HIF-1-mediated gene expression. Genes Dev 14: 391-396, 2000

Manuscript received January 10, 2006

Accepted in final form March 16, 2006.

Address reprint requests to: Randy L. Jensen, M.D., Ph.D., Department of Neurosurgery, University of Utah, 30 North 1900 East, Suite 3B409, Salt Lake City, Utah 84132. email: randy.jensen@ hsc.utah.edu. 